Administrative Issues Journal: Connecting Education, Practice, and Research, Summer 2017, Vol. 7, No. 1: 51-65. DOI: 10.5929/2017.7.1.4

\title{
Factors contributing to the persistence of African American and Hispanic undergraduate males enrolled at a regional predominantly White institution
}

\author{
Reginal R. Hall, Ed.D. \\ Tarleton State University
}

\begin{abstract}
The purpose of this study is to explore factors that may contribute to the persistence and graduation rates of African American and Hispanic undergraduate males enrolled at regional fouryear public universities in Texas. African American and Hispanic males have lower graduation rates in both secondary and post-secondary education than their White peers (Harper, 2010; Swail, Cabrera, Lee, \& Williams, 2013). The qualitative research investigated characteristics that exist among African American and Hispanic undergraduate males who have persisted and were retained at the university through their senior academic year. The research problem was explored through the lens of critical race theory and racial microaggressions. Focus group interviews were administered that allowed the researcher to explore the individual experiences of African American and Hispanic males regarding academic and non-academic factors that may have served as supports and/or barriers to their persistence. A thematic analysis was conducted to evaluate the qualitative data.
\end{abstract}

Keywords: diversity, microaggressions, retention, male undergraduates

he image of inclusiveness and diversity displayed on the marketing literature for universities is a misrepresentation of the pluralism of graduates assembled during commencement dates (Thomas \& Wingert, 2010). The graduation and persistence rates for Hispanic and African American male undergraduates continue to trail those of their White peer students, often by a large margin. Hispanic and African American students have greater access to higher education, but timely and successful matriculation has not been the correlated by-product. African American and Hispanic men are least likely to be retained and graduate when compared to their White and same-race females at all levels of collegiate degrees (Harper, 2013). With graduation rates being viewed as substantial measures of success for higher education and potentially impacting state funding and the reputation of the institution, more attention is necessary for understanding these traditionally underrepresented male collegians, especially those attending Predominately White Institutions.

HALL / DOI: 10.5929/2017.7.1.4 
The challenges that African Americans face on college campuses has been well-documented by Fleming (1984), who analyzed the experiences of African American students attending Predominately White Institutions (PWIs) and African American students attending Historically Black Colleges and Universities (HBCUs) (Harper, 2013). Predominately White Institutions may prove to be less inviting, less supportive, and less sympathetic to the needs of African American students (Allen 1992; Feagin et al. 1996; Fleming 1984; Strayhorn, 2008). If a large disparity in the representation of African American students is present on university campuses, the campus culture may overshadow the university's intentions of inclusiveness (Harper, 2013). One could presume these stressors would be experienced by other traditionally underrepresented groups. The challenges may influence persistence, retention, graduation, and academic performance of these groups.

Researchers have indicated that African American and Hispanic students may encounter critical obstacles when attending PWIs (Laird, Bridges, Holmes, Morelon, \& Williams, 2004). Strayhorn (2008) explained that negative labels about African American men create obstacles for these students to find the necessary faculty or staff support. Negative perceptions, along with other obstacles, may negatively influence their scholastic and co-curricular engagement within the university (Laird et al., 2004). Numerous researchers have explicated the importance of "fitting in" (Salinitri, 2005; Sorrentino, 2007; Strayhorn, 2008) and its relationship to student retention on university campuses. Students must effectively acclimate to universities' academic climate and social climates. University faculty, staff, and administrators have implemented various strategies to combat this problem throughout a student's matriculation (Harper \& Harris, 2012).

The intellectual and social engagement of African American and Hispanic students on college campuses may be necessary to improve the matriculation of more students of color. Bonner (2011) suggested that African American students must consider themselves as academically gifted in order to change their university experience. Positive interactions with a pluralistic group of peers, along with engagement in academic assistance programs, improved the enculturation process for Hispanic students (Swail, Cabrera, Lee, \& Williams, 2005). These ongoing and cooperative relationships with their pluralistic peer group determined Hispanic students' connectedness (Strayhorn, 2012). Harper (2013) indicated that most research published on undergraduate African American students at PWIs negatively focuses on the academic and non-academic elements, which severely undermine academic achievement and social engagement of these students.

\section{Traditionally Under-represented Males in Higher Education}

African American and Hispanic men are under-represented at most institutions of higher learning, maintaining low academic achievement when compared to their peers. Harper (2012) reported that, nationally, the six-year graduation rate for African American men attending public institutions of higher learning is $33.3 \%$ compared to $48.1 \%$ for students overall (Harper, 2012). The college graduation rates of African American men are the lowest amongst racial and gender categories (Harper, 2006; Strayhorn, 2012). Hispanic males trail slightly behind African American males in the hypothetical, yet proverbial, race where the rewards may result in future unemployment and low wage employment. More concerning to

HALL / DOI: 10.5929/2017.7.1.4 
universities should be the fact that only about $30 \%$ of Hispanics enrolling in higher education successfully matriculate, and only about $12 \%$ of Hispanic men over the age of 25 years have attained a bachelor's degree (Center for Community Development and Civil Rights, 2007).

\section{Significance of the Problem}

With graduation and retention rates significantly below their comparison groups, the disparity among African American and Hispanic men appears inexplicable. More African American and Hispanic male students are entering institutions of higher learning, which demands the establishment of effective strategies to increase not only access, but their graduation rates. The Bureau of Labor Statistics indicated that in 2018 and beyond, more than half $(60 \%)$ of future careers will demand more formal education credentials (Schott, 2012). The likely implications of the abysmal graduation rates of African American and Hispanic men include: (a) diminished long-term wealth accumulation; (b) greater income disparity among race and/also education level; and (c) diminishing of the nation's overall intellectual capital and global competitiveness.

\section{Critical Race Theory (CRT) and Racial Microaggressions}

The research problem is considered through the lens of critical race theory. The inequities and gaps in educational achievement, disciplinary reprimands, and economic status have been shown through a multitude of researchers and interest groups. Critical race theory seeks to analyze laws, policies, and systems that appear impartial but result in continued racial inequity (Solorzano, Villalpando, \& Oseguera, 2005). In this research, critical race theory was considered as a means to provide a perspective in analyzing the systematic practices that may function as barriers or supportive mechanisms of African American and Hispanic male undergraduates attending a Predominately White Institution (PWI).

Critical race theory recognizes the need for higher education to understand the varied perspectives and experiences of people of color (Solorzano et al., 2005). Critical race theory contends that cultures tend to behave and function in ways that tend to benefit the masses and those groups with more financial and social capital, and may continue a caste-like system for those with marginal forms of capital (Palmer, Maramba, \& Holmes, 2011).

Racism, classism, and sexism are often overtly and covertly included in operational processes and procedures. These covert, intended and unintentional practices can be considered microaggressions. According to Sue et al. (2007), "microaggressions are often unconsciously delivered in the form of subtle snubs or dismissive looks, gestures and tones" (p. 273). Racial microaggressions can be so prevalent that the actions are dismissed, overlooked, and rarely investigated (Delgado \& Stefancic, 1992; Johnson, 1998; Lawrence, 1987; Solorzano, 1998). Racial microaggressions can occur in a variety of forms from subtle to obtrusive, and, regardless of intent, have the ability to denigrate a certain group or individual (Sue et al., 2007).

HALL / DOI: 10.5929/2017.7.1.4 
Racial microaggressions are often manifested in the traditions and norms of our society. African Americans tend to be marginalized and may be considered less intelligent when compared to their White peers. These stereotyped perceptions may result in racial microaggressions. For example, young Black men are more likely to be tracked into less intellectually challenging curriculum, whereas their White peers are more likely to be placed in advanced and college preparatory courses (Palmer et al., 2011). Potential implications of the disparity between academic rigor of coursework often leaves African American high school graduates with critical deficiencies in their academic preparedness when compared to their White peers (Palmer, et al., 2011). Freire (1972) explicated that, when members of particular groups hear of their limited intellect and inability to learn, that they are lazy and worthless, result has been self-fulfilling prophecy and swayed of their ineptness. they tend to act in ways that would seem to confirm the assumption, having been convinced that they are, indeed, inept.

\section{Method}

\section{The Study}

A phenomenological study was conducted to investigate academic and non-cognitive factors that may have served as supportive or obstructive mechanisms to the persistence and graduation rates of African American and Hispanic undergraduate males enrolled at a regional, Predominately White Institution (PWI) in Texas. The following research questions were examined:

RQ 1: What academic factors identified by African American men and Hispanic men served as supports and/or barriers to their academic persistence?

RQ 2: What nonacademic factors identified by African American men and Hispanic men served as supports and/or barriers to their academic persistence in continuing their education at a selected regional four-year public university?

Examining the research questions required the exploration of the experiences of the traditionally underrepresented undergraduate males. Institutional Review Board approval was sought and granted. Data collection took place by conducting two focus group interviews. Student members were given pseudonyms to guarantee confidentiality throughout the research process.

The findings revealed a common theme shared by both African American and Hispanic men attending the PWI. In the interviews and process of answering the research questions, a common theme was discovered: regardless of race, academic, or non-cognitive factors, most of these young men experienced microaggressions that served as impediments or were redirected as motivation to persist in their collegiate studies. Braun \& Clarke (2006) explained that "a theme captures something important about the data in relation to the research question and represents some level of patterned responses or meaning within the data" (p. 82). A thematic analysis was conducted to assist in identifying, capturing, and explicating plausible relationships within the data (Braun \& Clarke, 2006). The thematic method of analysis can be utilized as an effective investigative tool to provide a more illustrative view of the data.

HALL / DOI: 10.5929/2017.7.1.4 
Thematic analysis serves a practical need to encapsulate the density obtained in the interviews (Guest, MacQueen, \& Namey, 2012). The range of themes allowed the researcher to have the data drive the process. After initial themes were uncovered, the researchers triangulated findings (Wilson \& Hutchinson, 1991).

The use of qualitative research allowed the researcher to gather important information beyond traditional measures of success, such as persistence and graduation rates. The qualitative research collected through the use of focus group interviews allowed the researcher to delve deeper into the success strategies and obstacles experienced by the traditionally underrepresented male undergraduate students.

Qualitative research included data obtained via focus group interviews with purposeful sampling of students. Purposeful sampling allowed the researcher to "select individuals and sites for study because they can purposefully inform an understanding of the research problem and central phenomenon in the study" (Creswell, 2007, p. 125). The researcher sought to identify a combination of ten participants for the study who self-identified as Hispanic/Latino or African American male undergraduate students at the university. The qualitative portion of the study investigated characteristics and experiences which may exist among successful African American and Hispanic undergraduate males who persisted and were retained at the university through their senior academic year.

\section{Institutional Characteristics of University}

Demographic data for the campus is included to highlight the diversity of undergraduate enrollment composition of the selected four-year regional university. However, the study focused mainly on African American and Hispanic male undergraduates enrolled within the university. The selected regional university reported an undergraduate enrollment of over 8,900 undergraduate students respectively. Approximately $13 \%$ of the selected university's undergraduate population self-identified as Hispanic (Texas Higher Education Coordinating Board, 2013). Hispanic females account for $8 \%$ of the total undergraduate population and Hispanic males accounted for $5 \%(5.28)$ of the undergraduate student enrollment in fall 2012. Hispanic males are outnumbered within the university and accounted for less than $40 \%$ of the reported Hispanic undergraduate population (THECB, 2013). African American males and females account for approximately $4 \%$ and $3 \%$ of the African American population at the selected regional university. The white undergraduate student population at the selected university comprised approximately $74 \%$ of the total university population, with white males accounting for slightly less than $30 \%$ of the total undergraduate population (THECB, 2013).

\section{Qualitative Results}

Purposeful sampling was used in selecting participants who met the identified criteria. The targeted participants included those undergraduate students who met the following criteria: self- identified as African American or Hispanic males; have less than 30 transfer hours from another institution; selfreported to have an overall grade-point average (GPA) of 2.25 or above; and were within two semesters of graduation. Two sets of focus group interviews were conducted on the campus during fall 2013 and

HALL / DOI: 10.5929/2017.7.1.4 
spring 2014. The qualitative data analyzed the perceptions of African American $(N=6)$ and Hispanic males $(\mathrm{N}=4)$ and those academic and non-academic factors which may have served as support mechanisms or as barriers to their persistence within the university.

The focus group interviews consisted of ten structured interview questions that were exploratory in nature to allow participants to freely discuss their perceptions of factors which may have aided or impeded their academic success at the institution. Both interviews were recorded via audio and video devices. Each participant was provided and returned their informed consent to participate before the data collection took place.

The qualitative portion of the research data was collected via the focus group interviews. The qualitative portion explored perceptions of African American and Hispanic undergraduate males who persisted at the university through their senior academic year.

\section{Emergent Theme: Microaggressions}

There were several themes that emerged from the two focus group interviews. During the thematic analysis of the transcript it was noted that acts of microaggressions had been experienced and expressed by many of the research participants. In several of the incidents, the students described the act as a barrier; however, others, while describing the situation as problematic, also chose to view it as a means of motivation, energizing their focus on persisting and completing the higher education.

The focus group questions inquired of academic and non-academic factors that had served as supports or barriers to participants' persistence within the university. The questions inquired about high school preparation, academic rigor of the major field of study, as well as the university faculty and staff's role. Other questions examined the participants' perceptions of non-academic factors that may have served as a support or barrier to their persistence such as financing college, familial support, campus engagement, and racial identity.

Research Question One: What academic factors identified by African American and Hispanic men serve as supports and/or barriers to their persistence in continuing their education at a selected regional fouryear public university?

University faculty and staff (barriers). One of the first themes that emerged was the perceptions of the university faculty and staff of the participants' academic persistence (see Table 1). Many of the students shared accounts of incidences of faculty members providing meaningful challenges and personal connections that were critical to their academic success such as providing mentoring and assisting with completing administrative documents. However, there were incidences that involved university faculty and/or staff that were perceived by the participants as potential barriers to their success.

HALL / DOI: 10.5929/2017.7.1.4 
Table 1

Summary of Microaggressions Experienced by Students (Academic Factors)

\begin{tabular}{|c|c|c|c|}
\hline Themes & \multicolumn{2}{|c|}{ Support and/or Barrier } & Summary \\
\hline \multirow{2}{*}{$\begin{array}{l}\text { University } \\
\text { Faculty \& } \\
\text { Staff }\end{array}$} & \multirow[t]{2}{*}{ Support } & \multirow[t]{2}{*}{ Barrier } & $\begin{array}{l}\text { Participants also indicated how low expectations and } \\
\text { stereotypes by faculty had served as a barrier. }\end{array}$ \\
\hline & & & $\begin{array}{l}\text { African American participants noted instances of being } \\
\text { perceived as an athlete. While Hispanics were often } \\
\text { stereotyped as less intelligent or unable to speak English. } \\
\text { Both viewed situations as added motivation to graduate. }\end{array}$ \\
\hline
\end{tabular}

These behaviors can be categorized into the various forms of microaggressions: microassault, microinsult, and microinvalidation (Sue et al., 2007). When asked about the faculty role in providing support or a barrier, Student A, an African American student, indicated, "When I was in the Ag. (Agriculture) department I felt like they (faculty) didn't care about me really and I didn't fit in." Student J, Hispanic student, related this observation:

And then some professors...that automatically assume, they assume stuff about you before you know. They think that you don't wanna work hard, so they don't take you seriously. And they think you don't wanna learn or whatever. So they may not pay as much attention to you in class when you have your hand up or something like that. That can be...it can set you back.

Student J, an undergraduate Hispanic male student continued:

One of my classes, I guess, one of my teachers stereotyped me just cause of my skin color. She thought I was originally from Mexico she was trying to speak to me slow. And she asked me what part of Mexico I was directly from and I think it's kinda like, kinda like a barrier, but kinda supportive, cause she automatically assumed I am from somewhere else when I'm from here. You know it's a motivational thing, cause I proved her wrong.

Racial microaggressions in subversive forms exist and must be understood by university faculty and administrators. These microaggressions can serve to empower some students but are not to be considered positive. Hurtado and Ponjuan (2005) conducted a study which found that Hispanic students were likely to become very cognizant of discrimination within the academic environment and on the university campus. Hispanic students may likely develop destructive self-esteem and create unhealthy perspectives of the campus environment due to their social standing, perceived cultural image, lack of connection to the university culture, and the lack of a "critical mass" of Hispanic students on the campus (Osegura et al., 2009).

Student A, who is senior student who had already achieved several academic accomplishments in his career posited, "I also take a lot of Science classes for PT (physical therapy), so I think sometimes there is

HALL / DOI: 10.5929/2017.7.1.4 
kinda a perception that oh he might not do as well because...he's an athlete or cause he's you know, African American." He continued, "I hit both stereotypes being a kines (kinesiology) major and an athlete (laughs) so I gotta really be...on top of my game like at all times."

Another profound experience was shared by Student J:

Coming out of my high school, I guess our academic counselor really didn't think any of the Hispanic males, the Hispanic or Black people would even go to college. They didn't even know.... We had a really small school, and they didn't even know who I was. I was kinda up there, I was like number 19 in my class, and she didn't even include me into the college fairs or any of that stuff assuming that I wasn't gonna go. And now I am actually one of the few that are actually in college.

Student K, Hispanic undergraduate male student reflected, "And the fact that I have an accent, automatically makes people think I am dumb. So that's kinda like my inspiration to keep on going." Despite these blatant acts of microaggressions and the negative stereotypes they encounter on a daily basis, these students have continued to remain resilient in their pursuit of their educational goals.

Research Question Two: What non-academic factors identified by African American Hispanic men served as supports and/or barriers in their academic persistence at selected regional four-year public university?

Stereotypes and negative perceptions (support). Very few of the participants viewed stereotypes and negative perceptions as supportive of their persistence within the university. However, many indicated these experiences often served as Student D noted, to add "fuel to the fire" (see Table 2).

Table 2

Summary of Microaggressions Experienced by Students (Non-academic Factors)

\begin{tabular}{|c|c|c|c|}
\hline Themes & \multicolumn{2}{|c|}{ Support and/or Barrier } & Summary \\
\hline $\begin{array}{l}\text { Stereotypes } \\
\text { and Negative } \\
\text { Perceptions }\end{array}$ & \multirow{3}{*}{ Support } & Barrier & $\begin{array}{l}\text { African American participants noted instances of being } \\
\text { perceived as an athlete, while Hispanics were often } \\
\text { stereotyped as less intelligent or unable to speak English. } \\
\text { Both viewed situations as added motivation to graduate. }\end{array}$ \\
\hline \multirow[t]{2}{*}{$\begin{array}{l}\text { Campus } \\
\text { Engagement } \\
\text { \& Campus } \\
\text { Environment }\end{array}$} & & \multirow[t]{2}{*}{ Barrier } & $\begin{array}{l}\text { Both African American and Hispanic students shared } \\
\text { positive experiences of their involvement in athletics, } \\
\text { student government, and student organizations as } \\
\text { supportive to their persistence. }\end{array}$ \\
\hline & & & $\begin{array}{l}\text { Participants indicated the campus environment was not as } \\
\text { supportive for African American or Hispanic students. }\end{array}$ \\
\hline
\end{tabular}

HALL / DOI: 10.5929/2017.7.1.4 
Student C described his thoughts: "I don't think it's been that much of a barrier though. I come from a small town, and I am used to that pretty much so I am...I really don't realize it anymore. I just kinda, you know, shake it off."

Stereotypes and negative perceptions (barrier). One of the most prominent themes that emerged from the research was the existence of stereotypes and prejudices these young men faced in their daily lives as college students. These accounts may be attributed to a university campus with a minority population of less than $25 \%$. Student B provided a plausible rationale for the stereotyping these men faced:

It's just, I guess, they just let the media, they just see what, they believe what they see on TV and believe we all act like that. And from other students, I kinda get that too. It's kinda like when I do certain things a different way. Like they kinda look at me...like he's kinda like a good black person. So, one of the good ones. We gotta keep him around. So...it's almost like you gotta constantly fight stereotypes.

Student C continuing to elaborate on Student B's statement, he surmised:

I think that's a good way to put it too. You constantly fight stereotypes here. People expect you to play sports. They expect you to be a kinesiology major. They don't expect you to be here as a plain old student just trying to get a degree and go on with life. That's the last thing they expect you. And if you tell them you don't play sports, they gonna keep asking you until you play something.

Student $\mathrm{H}$ explained:

And the only other barrier I would like to say at this time, I felt that some students, African American males, Hispanics, whatever it may be, are perceived as an athlete before anything. You may not necessarily be on the team here or anything like that. But, it can be upsetting if you (trying) try came to (name of the university) to be a student, and be approached as an athlete because of his skin color.

In another statement, Student H continued:

A lot of us are perceived as athletes, like off the bat which if you are not an athlete of course, it can be kinda frustrating, especially in the classroom atmosphere, because a lot, a lot of my experiences with professors in the past, if you're an athlete, they think that you think, that you just gonna come in there and get a grade, a free grade or something. That's what a lot of professors thought about us in the past. Sometimes they make it harder on us because of that, you know?

HALL / DOI: 10.5929/2017.7.1.4 
Despite the common experiences shared by both African American and Hispanic undergraduate males, these young men persisted to their senior year. Student $\mathrm{K}$ indicated how the misconceived perceptions have served as motivation to his success. This sentiment was echoed by Student D, who stated:

That's a form of motivation that kept me going through (too), a lot of people think that just because of my skin color or just because I'm an athlete that I can't pass classes or comprehend or do as good as everybody else. That's been a really big motivating factor.

Campus engagement and campus environment (support). Participants often mentioned the barriers presented by the low numbers of African American or Hispanic students on the campus. Positive interactions with a pluralistic group of peers and engagement in academic assistant programs improved the enculturation process for Hispanic students (2005); however, another participant, Student J, agreed that beneficial organizations are available and beneficial to students:

Coming to (name of university)... there's not a lot of Hispanics. From my town there's a lot of Hispanics. I didn't go to the school where all the Hispanics were at. I went to like the all-white one. It wasn't much of a culture shock coming here, but when I found AHLAS, the association of Hispanic and Latin American Students, it helped me to find more Latinos, you know, to hang out with and become friends with. It makes it easier going here, knowing that it's a predominately white school.

Campus engagement and campus environment (barrier). Within the literature review on college retention, researchers are often in agreement on the importance of campus engagement to student matriculation. African American and Hispanic males have often been described as less involved and less interested in both academic and co-curricular activities. During the thematic analysis, the campus engagement and campus environment were combined after exploring the experiences of many of the participants.

Student A discussed his campus and social engagement experiences: "I was lucky just being in a sport to kinda, like, just automatically have a clique to get into. It's rough.... You already kinda feel like you don't fit in here based off demographics." Student C, who was not a student athlete, also shared concerns of not "fitting in":

It can kinda make you feel like you don't belong, if you are not in one of those organizations. Like if you not a fraternity, you don't get to hang out with those guys. And if you are not on the football team, most likely, you don't get to hang out with those guys, but you just aren't around those guys. You don't see them. Until you find something that, you know, where you fit in, then it can become good support system.

Another participant expressed his concerns for the lack of opportunities to socialize and engage in student organizations due to the lack of racial diversity:

HALL / DOI: 10.5929/2017.7.1.4 
There's not a lot of like things for just like African American, you know, African American males at this school. If you are not in a sport, or cause I mean a lot of guys might not be able to fit in (name of fraternity- considered to be targeted for white students). (laughed) You know, if you're black or Hispanic, and then there's not a lot of stuff for you to really get into, except for just kinda being around each other, really.

Research indicates that for Black students, programs that explicitly focus on minimizing the stereotypes that threaten students' experience's through setting high expectations and providing significant encouragement to these students, assist in narrowing the gap in college achievement between Black and White students (Steele, 2010). The lack of a critical mass may bring forth important concerns with regards to the retention and engagement of African American students, as Student A explained:

I think like sometimes, you feel like some of the African American students on campus are just like, they don't wanna like branch out. I feel like some students here are too scared to really branch out and kinda like put themselves out there to meet different types of people and stuff.

Student C empathized with the plight of Hispanic male students attending the university, stating, "I can't speak for Hispanics either, but I think their situation is even worse. Cause as hard as it is for us to reach out.... They're a lot, much different culturally and you don't ever really see them out doing things, unless they're together." The students provided more insight to the lack of a pluralistic campus environment and how this has impeded the campus engagement for not only African American and Hispanic males but other traditionally underrepresented groups. Student $C$ exclaimed:

I think in general (name of university) needs to do a better job, catering to their minority students. Regardless of Hispanic or African-American, Thailandish; Thai; or Taiwanese, South Korean. All these kids are all the same to me, 'cause they are all displaced at this school. None of them have a place to go. They are all with the people they are similar to and typically in much smaller groups than everybody else at (name of university)... And there's nothing for them to do and if it is, it's some international program, a stereotypical program for them. I just think all the minorities here are at a disadvantage, just 'cause the university doesn't care about 'em to me, straight up. They don't do enough to make their stay here enjoyable.

Student $\mathrm{H}$ described an experience that is indicative of the "onlyness" African American students may experience explained by Harper's (2010) report on African American men in higher education:

Out of a class of 74, I am one of two African Americans in the class period. And the two of us are both males. And another one has joined in and...he's from Nigeria. So, I am the only American born African American in that class and probably has been for the rest of the time. And in the program, I think there's maybe four or five, African Americans period.

Another participant shared a similar occurrence of "onlyness" that may be unique to non-white students attending a Predominately White Institution. Student K posited:

HALL / DOI: 10.5929/2017.7.1.4 
I think being in the engineering department, like, once I started getting to the higher level physics, and engineering courses, I was usually the only non-white person in my classes.... I don't know if that's the reason I haven't been able to fit in or essentially cause they are a little nerdy, you know? It's just hard to fit in but you try to stay in there.

\section{Summary of Contributing Factors}

The implications from the focus group interviews and the thematic analysis provided additional insight into the academic and non-academic factors that may serve as supports or barriers to African American and Hispanic males. The perspectives shared by these collegiate men provided a more detailed account of their experiences at the selected university. Analyzing quantitative data may highlight the unique challenges faced by these young men. The thematic analysis allowed the researcher to identify common factors, as experienced by these young men that served as supports and/or barriers to their persistence within the university. These factors, whether academic or non-academic, were perceived as both supportive and/or an impediment toward their graduation goals. The participants within the focus groups self-described as being motivated individuals who used many of the barriers they encountered on the university campus as inspiration to persist and prove others wrong.

\section{Conclusion}

The comprehension and examination of racial microaggressions, their prevalence, and implications on traditionally marginalized populations in our society is vital and necessary to the creation of sound strategies to eliminate these behaviors (Sue et al., 2007). Racial microaggressions may be operating as invisible impediments to the success of many African American and Hispanic male undergraduates.

The current research on African American and Hispanic students may indicate these groups will continue to struggle, especially at Predominately White Institutions (Laird et al., 2004). If the goal is achieving an increase in the graduation of African American males and Hispanic males, then plans must begin with getting these students enrolled and engaged at four-year universities with an established reputation for graduating men of color (Lowe, 2012). The failure of these universities to create a "critical mass" of racially diverse students may continue to plague their academic success as they will likely avoid being involved in student organizations and enculturation within the university due to microinsults and microinvalidation. The challenges that exist for these two distinct groups have been highlighted within their examples of university faculty and staff who continue to enforce negative perceptions of their academic ability and language concerns just because of the color of their skin. Osegura et al. (2009) explicated that university administration must reevaluate how they can best serve the growing number of Hispanic and traditionally underrepresented students on their campuses.

Further research is needed to compare the academic and non-academic factors influencing African American and Hispanic males at other regional universities within Texas. This study was conducted at a Predominately White Institution located in a rural area within Texas. The factors and experiences

HALL / DOI: 10.5929/2017.7.1.4 
encountered by Hispanic and African American males may be different at a regional university within an urban area, a Hispanic-serving institution, or a Historically-Black college and university.

Other future research could consist of a comparison of the students' experiences from the varied campus that might provide more insight into the experiences, the supports, and the barriers these young men continue to face on college campuses. More research should also be encouraged to explore the perceptions and graduations rates of African American and Hispanic males enrolled in the research and flagship universities. African American and Hispanic males have been, and will continue to be a focal point of many researchers. There lies a great deal of hope that the amount of time and research allocated will result in substantial improvements in the academic success of these two groups. Our global competitiveness is contingent upon improving the education of African American and Hispanic males.

References

Allen, W. R. (1992). The color of success: African-American college student outcomes at predominantly white and historically Black public colleges and universities. Harvard Educational Review, 62, 2644.

Bonner, F. (2011). Negotiating the "in-between": Liminality and the construction of racial identify among African American male collegians. Journal of African American Males in Education, 2(2).

Braun, V., \& Clarke, V. (2006). Using thematic analysis in psychology. Qualitative Research in Psychology, 3(2), 77-101.

Center for Community Development and Civil Rights (CCDCR). (2007). Pathways to prevention: the Hispanic male dropout crisis. http://cdcr.asu.edu/publicationsfolder/Hispanic male droput07wcoverb.pdf

Delgado, R., \& Stefancic, J. (1993) Critical race theory: An annotated bibliography. Virginia Law Review, 79. 461-516.

Johnson, S. (1998). Unconscious racism and the criminal law. Cornell Law Review, 73, 1016-1037.

Fleming, J. (1984). Blacks in College: A comparative study of students in black and in white institutions. Jossey-Bass, New York, NY.

Freire, P. (1972). Pedagogy of the oppressed. New York: Herder and Herder.

Fries-Britt, S., \& Turner, B. (2002). Uneven stories: Successful black collegians at a black and a white campus. The Review of Higher Education, 25(3), 315-330.

Guest, G., MacQueen, K., \& Namey, E. (2012). Applied Thematic Analysis. Sage Publications, Thousand Oaks, CA.

Harper, S. R. (2006). Peer support for African American male college achievement: Beyond internalized racism and the burden of "acting White." Journal of Men's Studies, 14(3), 337-358.

HALL / DOI: 10.5929/2017.7.1.4 
Harper, S. R. (2012). Black male student success in higher education: A report from the national black male college achievement study. Philadelphia: University of Pennsylvania. Center for the Study of Race and Equity in Education.

Harper, S. R. (2013). Five things student affairs administrators can do to improve success among college men of color. Washington, DC: NASPA.

Harper, S. R., \& Harris, F. (2012). Men of color: A role for policymakers in improving the status of black male students in U.S. higher education. Philadelphia: University of Pennsylvania. Center for the Study of Race and Equity in Education.

Hurtado, S. and Ponjuan, L. (2005). Latino educational outcomes and the campus climate. Journal of Hispanic Higher Education, 4, 235.

Johnson, S. (1998). Unconscious racism and the criminal law. Cornell Law Review, 73, 1016-1037.

Laird, T. F., Bridges, B. K., Holmes, M. S., Morelon, C. L., \& Williams, J. M. (2004). African American and Hispanic student engagement at minority serving and predominately white institutions. Paper presented at Annual Meeting of the Association for the Study of Higher Education. November 2004.

Lawrence, C. (1987). The id, the ego, and equal protection: Reckoning with unconscious racism. Stanford Law Review, 39, 317-388.

Lotkowski, V. A., Robbins, S. B., \& Noeth, R. J. (2004). The role of academic and non-academic factors in improving college retention: $A C T$ policy report.

Lowe, F. H. (2012). Plan to graduate more black men. North Star News. (09/06/2012).

Palmer, R. T., Maramba, D. C., and Holmes, S. L. (2011). A contemporary examination of factors promoting the academic success of minority students at a predominately white university. Journal of College Student Retention, 13(3), 329-349.

Reynolds, C. V. (2012). Targeting Blacks and Hispanics for college success: No man left behind. Retrieved from www.diverseeducation.com

Salinitri, G. (2005). The effects of formal mentoring on the retention rates for first-year, low achieving students, Canadian Journal of Education, 28(4), 853-873.

Schott Foundation for Public Education (2012). The urgency of now: The Schott 50 state report on public education and black males. Cambridge, MA.

Solorzano, D. (1998). Critical race theory, racial and gender microaggressions, and the experiences of Chicana and Chicano scholars. International Journal of Qualitative Studies in Education, 11, 121136.

Solorzano, D. G., Villalpando, O., \& Oseguera, L. (2005). Educational inequities and Latina/o undergraduate students in the United States: A critical race analysis of their educational progress, Journal of Hispanic Higher Education, 4, 272.

HALL / DOI: 10.5929/2017.7.1.4 
Sorrentino, D. M. (2007). The SEEK mentoring program: An application of the goal-setting theory, Journal of College Student Retention: Research, Theory \& Practice, 8(2), 241-250.

Steele, C. (1999). Thin ice: Stereotype threat and black college students. Atlantic-Boston, 284, 44-54.

Strayhorn, T. L. (2008). The role of supportive relationships in facilitating African American males' success in college, NASAP Journal, 45(1) 26-48.

Strayhorn, T. L. (2012). College students' sense of belonging: A key to educational success for all students. Routledge. New York, NY.

Sue, D. W., Capodilupo, C. M., Torino, G. C., Buccerri, J.M., Holder, A. M., Nadal, K. L., and Esquilin, M. (2007). Racial microagressions in everyday life: Implications for clinical practice. American Psychologist, 62(4), 271-286.

Swail, W. S., Cabrera, A. F., Lee, C., \& Williams, A. (2005). Hispanic students and the educational pipeline. Part III: Pathways to the bachelor's degree for Hispanic students. Washington, DC: Educational Policy Institute and Lumina Foundation for Education.

Swail, W. S., Redd, K. E., \& Perna, L. W. (2003). Retaining minority students in higher education: A framework for success. ASHE-ERIC Higher Education Report, 30(2).

Texas Higher Education Coordinating Board (THECB) (2012). Closing the gaps progress report 2012. Retrieved from http://www.thecb.state.tx.us/Reports/

Thomas, E., \& Wingert, P. (2010, February 18). Minority report: American universities are accepting more minorities than ever. Graduating them is another matter. Newsweek.

Wilson, H. S., \& Hutchinson, S. A. (1991). Triangulation of qualitative methods: Heideggerian hermeneutics and grounded theory. Qualitative Health Research, 1(2), 263-276. doi:10.1177/104973239100100206

Zhao, Y. (2009). Catching up or leading the way: An American education in the age of globalization. Alexandria, VA. ASCD

\section{About the Author}

Reginal (Reggie) R. Hall, Ed.D. (rhall@tarleton.edu) is an Assistant Professor in the Management Department in the College of Business at Tarleton State University. He holds an Ed.D. in Educational Leadership and has achieved both the PHR and SHRM-CP human resource management national certifications. As a faculty member, he has instructed undergraduate human resource management courses and a variety of other management courses. His research interests include workplace bullying issues, ethical treatment of employees, and diversity and inclusion in organizations. Reggie Hall has served several years within his career in higher education with a dual appointment, in an administrative position within the university diversity and inclusion office, as well as being actively engaged on a myriad of university faculty and student life committees throughout his higher education career.

HALL / DOI: 10.5929/2017.7.1.4 